\title{
Constitutional Protection Against Discrimination of Homosexuals
}

\author{
Kees Waaldijk \\ University of Limburg
}

\begin{abstract}
A brief review of equality for homosexuals prior to 1983 is presented followed by the introduction and explanation of the relevant section of the revised edition of the Dutch Constitution (enacted in 1983). The possible impact of this section on the abolishment of discrimination based on sex and sexual orientation is discussed.
\end{abstract}

\section{EQUALITY BEFORE 1983}

"All people who are on the territory of the State, have an equal claim to protection of person and goods." These words could be read in the Dutch constitution from 1815 till 1983. ${ }^{1}$ The Dutch Supreme Court ${ }^{2}$ however, hardly ever invoked them. This does not mean that the notion of equal protection has been legally unimportant in The Netherlands, for, in fact, the principles of equal protection of the various religions can be seen as one of the roots of this state. But equal protection has never been as major a legal topic in The Netherlands as we are told it its in the United States. This can in part be explained by the fact that the judiciary in The Netherlands does not check the constitutionality of parliamentary legislation; this is left to parliament itself. Unconstitutional statutes are valid and binding. Therefore, not only is the equal protection clause not a major theme in Dutch law, but the

Kees Waaldijk is a lecturer in the Department of Public Law at the University of Limburg, and was coordinator of the National Working Group on Legislation of the COC. Correspondence may be addressed to the author, Faculty of Law, Rijksuniversiteit Limburg, Postbus 616, 6200 MD Maastricht, The Netherlands.

(C) 1987 by The Haworth Press, Inc. All rights reserved. 
whole constitution as a legal instrument is not as important as it is in the United States, where judges do review the constitutionality of statutes. Even where judicial control or constitutionality is possible, i.e., where laws made by bodies other than parliament are concerned, equal protection has not been a frequently discussed topic. The recently increasing attention paid in The Netherlands to the notions of equality and non-discrimination could be partly explained by the political emergence of new groups of the population: colored people from former colonies, migrant workers, feminists, and gay people.

\section{EQUALITY SINCE 1983}

All persons in the Netherlands shall be treated equally in equal circumstances. Discrimination on the grounds of religion, belief, political opinion, race or sex or on any grounds whatsoever shall not be permitted.

Since 1983 these have been the opening words of the completely revised Dutch constitution. ${ }^{3}$

This change in the constitutional wording of the principle of equality can be seen as a result of the increasing concern for nondiscrimination, referred to in the first paragraph. It is as yet uncertain whether this new phrasing will have much impact on legal discussions, in court or elsewhere.

It should be noted that the Dutch Constitution after the 1983 revision still forbids judicial review of acts of Parliament. In this direction the importance of the Constitution will not increase. Nevertheless, there are two features of the revised Constitution which allow for some speculation about the growing constitutionalization of human rights in The Netherlands. First, the revised Constitution opens with a systematic catalogue of no less then 23 human rights, which is more than the rights which were scattered in various paragraphs of the Constitution in its 
pre-1983 text. This increased constitutional attention for human rights has been accompanied by an increase in the quantity of legal writing on the subject. One would expect this would lead those in government and those controlling or criticizing the government to take constitutionally protected human rights more often into account. Several examples of such increasing constitutionalism may already be noticed, one being that in discussions between government authorities and the gay movement both parties now frequently refer to the new non-discrimination clause.

Second, during the parliamentary debates leading to the recent revisions of the Constitution, the legislature (i.e., both Government and Parliament) made it clear that the scope of human rights must not be confined only to so called vertical relations between citizens and government authorities. Therefore, it is possible and likely that both the courts and the legislature will apply constitutionally protected human rights to so-called horizontal relations between citizens. A controversial example of this can be found in a proposal by the government to forbid citizens and private institutions from discriminating between men and women, heterosexuals and homosexuals, married and unmarried people. (This proposal will be discussed later in this article.)

\section{“OR ANY OTHER GROUNDS WHATSOEVER'}

"All persons in the Netherlands shall be treated equally in equal circumstances. Discrimination on the grounds of religion, belief, political opinion, race or sex shall not be permitted."

This was the text of the original government proposal for a constitutional phrasing of the principle of equality, ${ }^{4}$ a proposal which caused critical comments both in the Council of State ${ }^{5}$ and in the Parliament. The text was said to suggest that discrimination on grounds other than those named was still permitted. It was especially regretted that discrimination on account of 
homosexuality was not covered in the proposal. The possibility of adding "sexual orientation" as a sixth ground was rejected because that would leave other forms of discrimination uncovered and therefore permitted. Eventually, Government and Parliament agreed on adding the words "or any other grounds whatsoever."

This amendment to the original proposal brought the Dutch Constitution into line with several international treaties to which The Nethe:lands is a party. The International Covenant on Civil Political Rights, for example, provides that "the law shall prohibit any discrimination and guarentee to all persons equal and effective protection against discrimination on any ground such as. . .or other status. " 6 Unlike the history of the International Covenant, the legislative history of the amendment to the original proposal for the revised Dutch Constitution leaves it beyond doubt that the Constitution regards sexual orientation as an "other ground" referred to in the non-discrimination clause.

\section{A SPECIES OF SEX DISCRIMINATION}

"By discrimination on account of sex is also understood discriminating on account of behavior or expressions contrary to qualities or characteristics ascribed to the sex of the person(s) involved." 7

In 1977 the Government Advisory Committee on the Emancipation of Women proposed making a law against all forms of discrimination on account of sex, i.e., being male or female, including those referred to in this complex formula. If one considers the tendency to fall in love with men as a "characteristic", traditionally ascribed to women, and the tendency to fall in love with women as a "characteristic" traditionally ascribed to men, then discrimination on account of homosexuality can be viewed as a form of discrimination on account of sex. A similar line of thought has been tried in the Congress of the United States during the debates concerning the Equal Rights Amendment, and in 
the United Kingdom in several court cases under the Sex Discrimination Act. This line of thought, however, was adopted by neither the U.S. Legislature nor the U.K. Judiciary. ${ }^{8}$ Although this approach was not generally adopted in The Netherlands, it nevertheless has had some impact: discrimination because of sex and discrimination because of sexual orientation are now widely seen as related forms of discrimination. Plans are being developed for a statute prohibiting both sex discrimination and sexual orientation discrimination. The Dutch gay movement stresses this link because of the common roots of the oppression of women and homosexuals.

\section{THE COURTS}

"Plaintiff has not been dismissed because of a characteristic she was afflicted with, but she was dismissed because of acts and behavior on her part." 9 For this reason a lower judge accepted the contested dismissal of a woman employee who had openly begun a love affair with one of her female colleagues. At this writing this is the most recent (1972) known case in which a Dutch judge allowed discrimination on account of homosexuality. He clearly made a distinction between a homosexual disposition and homosexual behavior, only the latter justifying dismissal.

Cases involving discrimination against homosexuals are very rare in Dutch law. ${ }^{10}$ Therefore, it is not predictable what judges will say when they hear such a case. In 1982 an appeal court decided that a homosexual disposition as such could not be regarded as a disease or defect justifying dismissal. "l Whether dismissal because of homosexual behavior or relations will still be accepted by courts is unknown. This underlines the importance of an Equal Treatment Act forbidding not only discrimination on account of homosexual disposition, but also discrimination on account of homosexual behavior. The number of people discriminated against on these grounds by far exceeds the number of 
court cases involving discrimination against gays, a phenomenon explained perhaps by the negative decisions courts have handed down in earlier decades. Homosexuals who are discriminated against seem to have more faith in political activity or use of publicity as means of seeking redress; that is; if they are already emancipated enough to seek redress in the first place.

\section{A PARLIAMENTARY DESIRE}

"To introduce a bill aimed against all types of discrimination on account of sex (including discrimination on account of homosexuality) and of discrimination on account of marital status." 12 This is what more than $90 \%$ of the members of the Dutch Chamber of Representatives asked the government to do in 1978. The government responded by establishing two committees of civil servants. The first was to prepare a bill against sex discrimination, the second to examine the consequences of and the possibilities for a prohibition of discrimination on account of homosexuality.

\section{A PINK GOVERNMENT REPORT}

"The fundamental conclusion is, on the one hand, that the social opposition against homosexuality has considerably diminished, on the other hand, that actual discrimination on account of homosexuality still occurs on a large scale."'13 So concluded the second government committee mentioned above. Thus, the committee resolved that a legal prohibition of discrimination on account of homosexuality was both socially acceptable and socially necessary. The government used the report of the committee during the preparation of the draft of the Equal Treatment Act to be discussed in the next paragraph. The report was published by the government in a pink cover. 


\section{A DRAFT TREATMENT ACT}

"Considering that the attainment of a general recognition of the equivalence of people in society will be highly served if unjustified discrimination between persons on account of sex, homosexuality or marital status is counteracted in social life and public administration," 14 the Dutch government published in 1981 a preliminary draft of an Equal Treatment Act.

Not yet a bill introduced in Parliament, but an idea put forward by the government so that all members of society could express their thoughts about it, the draft indeed created a lot of reactions. The proposal consisted of a new statute prohibiting, in general, unreasonable differential treatment on account of sex, homosexuality (including behavior), marital status, or family responsibility, and prohibiting, in particular, all differential treatment on these grounds in certain well-defined areas. Those areas included labor, education, trade, and public administration. Certain fields were excluded from the general or the specific prohibitions of discrimination, including religion, emanicpation movements of women or homosexuals, private life, and scientific research. The act would be concerned only with discriminatory treatment, whereas discriminatory expressions would be covered by a proposed criminal law prohibiting incitement of sexual violence, hatred, or discrimination. People who commit any kind of discrimination prohibited by the Equal Treatment Act would be liable to the general sanctions of civil or administrative law, or both, applicable to the field in which the discrimination occurred. The draft did not provide specific new sanctions, criminal or otherwise. The proposed act, however, was to establish a Commission for Equal Treatment, whose task would be to look into cases of forbidden discrimination and give its opinion about them, as well as to mediate between the discriminators and those discriminated against. The published and unpublished opinions of the commission, however, would not be binding. 
This whole preliminary draft was an elaboration of some of the existing laws relating to equal treatment of men and women in the field of labor. The European Economic Community obliged the Dutch legislature to make those laws during the 1970s. The new act, if enacted, would have a wider scope, covering more grounds (including homosexuality) and more fields of social life. At this writing Norway is the only European country with specific legislation against discrimination of homosexuals. ${ }^{15}$ (France enacted a similar law in 1985.)

\section{COLLIDING CONSTITUTIONAL RIGHTS}

Critical reactions to the preliminary draft of an Equal Treatment Act came from very different directions. Several emancipation groups criticized the fact that discrimination against paedophilia, transvestism, and so forth was not included in the draft. Some religious groups, on the other hand, strongly objected to the narrow exception for religious activities, holding the view that all religiously inspired activities should be exempted from a legal prohibition of discrimination on account of homosexuality. The draft only provided an exemption for activities directly related to religious worship. This criticism developed into a hot political issue focusing on the "right" of christian schools to refuse to employ homosexual teachers, the main problem the government has to solve before it can introduce a final Equal Treatment Bill in Parliament. The state-funded private religious educational system is one of the traditional political strongholds in Dutch society. In addition, the freedom of parents to organize their own schools for their children is constitutionally protected. ${ }^{16}$

Here again emerges the importance of the new first article to the Dutch Constitution. When two rights collide, e.g., the right not to be discriminated against and the right to be master of one's own school, it is of at least symbolic importance that not only 
one but both of the rights are constitutional rights. In the Dutch legal system, this balancing of constitutional rights is mainly a task for the political bodies, the Government and Parliament. The text of the Constitution before 1983 did not clearly forbid discrimination against homosexuals; since 1983 it does. A balance is thereby restored between groups which won constitutional protection at the end of the last century, i.e., christian parents of school-age children, and groups which won constitutional protection during the 1970 s and 1980 s, i.e., gays, women, and so forth. The Dutch constitution does not solve this conflict of interests, but it does give equal support to different groups. Whether denominational schools will, in the end, be forbidden to refuse to employ homosexual teachers on the basis of their sexual preference depends on the outcome of political discussions, not on mere interpretation of the Constitution. ${ }^{17}$

\section{DISCRIMINATING STATUTES}

"What is laid down in this act is not applicable to discrimination contained in any other act." 18 This provision is contained in the preliminary draft of the Equal Treatment Act. It was much criticized, but probably will also be included in a final Equal Treatment Act. It implies that all discrimination based on acts of Parliament will still be legal after the Equal Treatment Act comes into force. As mentioned earlier, statutes containing unconstitutional discrimination cannot be declared void by Dutch courts. ${ }^{19}$ For that reason, neither the new non-discrimination clause in the constitution, nor a prospective Equal Treatment Act including a prohibition of discrimination against homosexuals will guarantee that all existing statutes which discriminate against homosexuals will be changed. All hopes in that regard have to be placed on political forces in the legislative process. ${ }^{20}$ The statute which most explicitly discriminated against homosexuals was abolished in 1971. Until then that statute had 
made it a criminal offense for adults to engage in homosexual acts with people between 16 and 21 years of age. ${ }^{21}$

\section{A HOMOSEXUAL MARRIAGE?}

"The man can at the same time only with one woman, and the woman only with one man be united in marriage." 22 This section of the Dutch Civil Code is supposed to exclude homosexual marriage. Whether or not one sees marriage as a valuable institution, it seems obvious that the legal impossibility of a homosexual marriage clearly contradicts the revised Dutch constitution. Since the courts can do nothing about this type of unconstitutional discrimination, the only way of abolishing it is by legislation. Yet it is unlikely a law will be passed on this point. First, it is not a topic at all in Dutch politics. Second, there are strong potential opponents against the idea of a homosexual marriage, especially in orthodox religious circles. And third, the national committee of the main Dutch gay organizations, the COC, has declared the possibility of marriage for homosexuals just as undesirable as the whole institution of marriage. The gay movement does play a role in the movement for equal rights for nonmarital and marital relations, and a more active role in the movement for equal rights for people with and without permanent domestic relations. This is considered more important than a lobby for homosexual marriage. In these political campaigns the constitutional non-discrimination clause can be invoked. Yet it seldom is.

\section{CONCLUSION}

The Dutch Constitution, by prohibiting all discrimination on any ground whatsoever, forbids discrimination because of homosexuality. This constitutional provison has not had many 
direct legal consequences. The effects of the constitutional prohibition of discrimination largely depend on political forces. The new first article of the Constitution can both inspire and legitimate those political forces aiming at an Equal Treatment Act prohibiting in some detail discrimination against homosexuals in various fields of social life, and those forces aiming at an abolition of all statutory discrimination against homosexuals and unmarried people.

\section{NOTES}

1. "Allen die zich op het grondgebied van het Rijk bevinden, hebben gelÿke aanspraak op bescherming van persoon en goed." Section 4 of the Dutch Constitution before 1983 .

2. Hoge Raad.

3. "Allen die zich in Nederland bevinden, worden in gelÿke gevallen gelijk behandeld. Discriminatie wegens godsdienst, levensovertuinging, politieke gezindheid, ras, geslacht of op welke grond dan ook, is niet toegestaan." Section 1 of The Dutch Constitution since 1983.

4. For the parliamentary debates and the original proposals see: Algehele Grondewetsherziening, eerste lezing, deel Ia, Grondrechten, Tweede Kamer (General Revision of the Constitution, First Reading, Part Ia, Second Chamber); Den Haag: Staatsuitgeverij, 1979 (government publication with original texts).

5. Raad van State.

6. Section 26 of the International Covenant on Civil and Political Rights, New York, 1966.

7. "Onder het maken van onderscheid naar geslacht wordt mede verstaan het maken van onderscheid op grond van gedragingen of uitingen in strijd met aan het geslacht van de betrokkene(n) toegeschreven eigenschappen of kenmerken." Advies over de Wenselijkheid van Een Wet Tegen seksediskriminatie (Advice on the Desirability of an Act Against Sex Discrimination); Emancipatiekommissie, Rijswijk, 1977, p. 38 .

8. For the U.S. see: Babcock, B. A. and others (1975) Sex discrimination and the law. Boston: Little, Brown. For the U.K., see: Pannick, D. (1983) Homosexuals, Transsexuals and the Sex Discrimination Act. In Public Law, Summer 1983, pp. 279-302.

9. "Eiseres is immers niet ontslagen op grond van een eigenschap, waarmee zij is behept, maar zij werd ontslagen op grond van daden of gedragingen harerzijds," Kantonrechter (local judge) Leeuwarden, 29-02-1972, Nederlandse Jurisprudentie (Dutch Law Reports) 1972, 356.

10. A list of 54 reported cases on homosexuality is included in: Waaldijk, K., "Handelingen welke de indruk konden wekken van tederheden zoals die tussen geliefden plegen te worden gewisseld." Over de woorden die de rechter gebruikt om 
homoseksualitett aan duiden ("Acts which could convey the impression of being like tender exchanges between lovers " On the word judges use to refer to homosexuality), published privately, Rotterdam 1981

11 Centrale Raad van Beroep (appeal court for public servants) 17 6-1982, MAW in Nederlands Jurtstenblad (Dutch Lawyers Weekly), 1983, p 65 and in Militair Rechtelyjk Tydschrtft (Dutch Journal of M1litary Law), 1983, p 300

12 "Een ontwerp van wet in te dienen dat zich richt tegen alle vormen van discriminatie op grond van geslacht, daarbij inbegrepen discriminatie op grond van homofilie, en huwelıjkse staat " Motion of the Chamber of Representatives, Kamerstukken $I I, 1978-1979,14496$, nr 22, (parliamentary papers)

13 "'Basisconclusie is, enerzijds, dat de maatschappelıjke weerstanden tegen homofilıe aanzienlıjk zijn vermınderd, anderzıjds, dat feitelıjke discrimınatıe wegens homofilie nog op ruime schaal voorkomt "Advies Over de Wettelyke Bestryding van Discriminatie Wegens Homofilie (Advice on Statutory Measures Against Discrimination on account of Homosexuality), Minısterie van CRM (Ministry of Welfare), Rij-

14 "Alzo $\mathrm{W}_{1 \mathrm{j}}$ in overweging genomen hebben dat het bereiken van een algemene erkennıng van de gelıkwaardigheid van mensen in de samenleving in hoge mate gediend wordt indien ongerechtvaardigd onderscheid tussen personen op grond van geslacht, homofilie of huwelıjkse staat wordt tegengegaan in het maatschappelijk leven en het openbaar bestuur " Considerans (preamble) of Voorontwerp van een Wet Gelyke Behandeling (Prelıminary Draft of an Equal Treatment Act), Ministerie van CRM, (Ministry of Welfare), Rijswijk, 1981, p 7

15 Artıcles 135a and 349a of the Norwegian Crimınal Code See IGA pink book 1985, Amsterdam COC-magazyn, 1985

16 Section 208 of the Constitution before 1983 Section 23 since 1983

17 See Waald $1 \mathrm{k}, \mathrm{K}$ and R A P Tielman, Grondrechtenafweging en de Wet Gelyke Behandeling (Weighing fundamental rights and the Equal Treatment Act), Interfacultaire Werkgroep Homostudies, Riyksuninversiteit Utrecht, 1984 (A shorter version of this report is published in NJCM-Bulletın/Nederlands Tydschrift voor de Jurists), May/June 1984, pp 208-228

18 "Het in deze wet bepaalde is met van toepassing op onderscheid, dat gemaakt wordt in een andere wet "Section 83 of the draft mentioned in Note 13

19 Dutch courts do to a certain degree have the competence to declare statutes not binding if they so consider them to be in contravention of international treaties on human rights These international aspects I leave undiscussed in this article

20 See Waaldıjk, K, Het recht en de homoseksuele vrijheid (The Law and Homosexual Freedom), in Homojaarboek 2, Amsterdam Van Gennep, 1983, pp

21 See the article of Maarten Salden in this issue

22 "De man kan tegelıjkertıjd slechts met een vrouw, de vrouw slechts met een man door het huwelijk verbonden zijn " Section 34 of Book 1 of the Dutch Civil Code 